\title{
Robotic Milking and Its Effect on Fertility and Cell Counts
}

\author{
T. A. M. Kruip, ${ }^{*}$ H. Morice, ${ }^{*}$ M. Robert, ${ }^{*}$ and W. Ouweltjes† \\ ${ }^{*}$ Institute of Animal Science and Health (ID-Lelystad), \\ PO Box 65, 8200 AB Lelystad, Netherlands \\ †Research Institute for Animal Husbandry, \\ PO Box 2176, 8203 AD Lelystad, Netherlands
}

\begin{abstract}
The aim of this study was to analyze the effect of robotic milking (RM) on fertility and somatic cell counts (SCC) among dairy herds participating in the national Dutch milk recording system. It was hypothesized that RM, and a higher milking frequency in general, would have negative effects on fertility, due to expected and supposed deeper negative energy balance (NEB). Herds increasing milking frequency from two to three times daily consistently had increased production. Milk production during RM was intermediate between the amounts obtained by milking twice versus three times a day. Milking three times a day and the associated higher production had no significant effect on reproductive measures such as nonreturn rate at $56 \mathrm{~d}$ post insemination (NR56) or days to first service. Although RM did not affect NR56, use of the robot was associated with an increase in days to first service. An increase in milking frequency from two to three times daily did not affect SCC, but SCC were significantly increased after milking with the robot. Robotic milking has a significant positive effect on production and no negative effect on fertility as measured by NR56. The effect of RM in increasing days to first service appears due to reasons other than increased production and a more NEB. Increased SCC during RM is potentially of concern. From the data available, the relationship of RM to clinical mastitis could not be determined but this aspect needs further attention.
\end{abstract}

(Key words: robot, milking, fertility, cattle)

Abbreviation key: $\mathbf{R M}=$ robotic milking, $\mathbf{N E B}=$ negative energy balance, $\mathbf{N R - 5 6}=$ nonreturn rate at $56 \mathrm{~d}$ after insemination, $\mathbf{2 x}, \mathbf{3 x}=$ number of times cows were milked daily.

\section{INTRODUCTION}

Because of the effect milking robots have on increasing milk production in dairy cattle, it was expected that

Received October 11, 2001.

Accepted April 16, 2002.

Corresponding author: T. A. M. Kruip; e-mail: T.a.m.kruip@ id.wag-ur.nl. robotic milking (RM) could have an effect on fertility. Experiments have been implemented on the problem of reduced fertility when milk production increases (Butler and Smith, 1989; Nebel and McGilliard, 1993). However, Stefanowska et al. $(1995,1996)$ reported that the increased milking frequency with a milking robot, leading to higher yield, does not delay the occurrence of estrus postpartum if a special herd management (Devir et al., 1993) is implemented. Other researchers (Barnes et al., 1990) found similar results: increasing milking frequency leads to higher milk yield and efficiency of production without loss of reproductive efficiency. However, all those studies on the effects of milking frequencies on production and fertility were performed in relatively small herds and under experimental circumstances.

Again under experimental circumstances, neither milking three times per day (3x; Waterman et al., 1983) nor automatic milking (Klungel et al., 2000) affected udder health. Yet, tendencies have been shown that when there is an increase in milking frequency, a transitory increase in milk SCC has been observed (Hillerton and Winter, 1992).

For these reasons, data on fertility and SCC of cows that have been milked by robot from parturition onwards under commercial farm conditions and over a long period of time were examined and analyzed.

\section{MATERIALS AND METHODS}

The data for this study came from the National Dutch data file (CR Delta, Arnhem, The Netherlands) for milk recordings collected from 1994 to June, 2000. Data from herds milking twice or three times per day $(\mathbf{2 x}$ and $3 \mathbf{x}$, respectively) were available over all those years. Data from herds using robotic milking were available from 1996 through June, 2000 (Table 1).

The number of farms with a milking frequency of $2 \times$ is just an arbitrary and a select number, meant as a reference. Table 1 illustrates that the number of farms with consistently $3 \times$ milking is relatively steady but low, whereas the number of farms with RM has increased, particularly since 1997 . The dataset contains information about: number of lactations, milking fre- 
Table 1. Number of farms with two $(2 \times)$ and three $(3 \times)$ times milking per day and of robotic milking (RM) under study in this paper.

\begin{tabular}{lllr}
\hline $\begin{array}{l}\text { Milking } \\
\text { frequency }\end{array}$ & $2 \times$ & $3 \times$ & $\mathrm{RM}$ \\
\hline 1994 & 364 & 24 & 0 \\
1995 & 358 & 29 & 0 \\
1996 & 357 & 35 & 2 \\
1997 & 352 & 43 & 4 \\
1998 & 346 & 53 & 63 \\
1999 & 278 & 47 & 87 \\
2000 (through June) & 250 & 37 & 84 \\
\hline
\end{tabular}

quency for each test day, dates when milking frequency changed, number of samples taken (number of cows $\times$ number of test days) per milking frequency, average test-day yields per herd, weighted average SCC (cells/ $\mathrm{ml} \times 1000$ ) per herd along with calving and insemination dates. From those data, the following variables were calculated: average yield and cell counts for the three milking frequencies and days to first service and nonreturn rate at $56 \mathrm{~d}$ (NR56) after first insemination.

The composition of the herd groups included opportunities for two levels of comparison:

1) Comparison among the three milking systems over different farms: Farms with a milking frequency of two times per day $(2 \times)$, farms with a milking frequency of three times per day $(3 \times)$ and farms with RM. The three groups varied in terms of number of animals, duration of use, and management strategy. Differences caused by management strategy can be confounding. Therefore, within each farm where data were available, the differences between the results obtained with one way of milking, and the results obtained with another way of milking were calculated leading to the second approach:

2) Comparison of the farms that have changed their milking system in the period under investigation, i.e., a comparison between systems within farms. In this case, for each farm, the differences between the results after and before the change were calculated. The new groups for comparison were: from $2 \times$ to $3 \times$; from $2 \times$ to $\mathrm{RM}$; from $3 \times$ to $\mathrm{RM}$ and from $3 \times$ to $2 \times$.

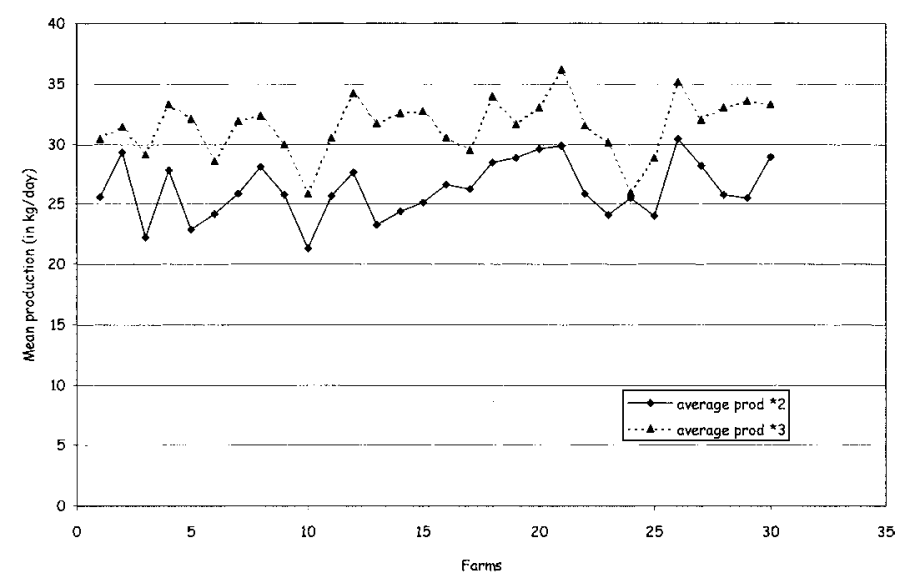

Figure 1. Mean production increase on 30 farms at change from two to three times milking per day.

\section{Statistics}

The mean test-day yield, the mean SCC, the NR56, and the mean days to first service per herd and per milking system were analyzed by ANOVA. Differences between groups were tested for significance by pairwise comparison in the Student's $t$-test (Genstat 5, fourth version for windows).

\section{RESULTS}

\section{Milk Production}

Across all farms in the dataset, the increase of milking frequency led to higher average test-day yield $(P<$ 0.001). Farms with $3 \times$ milking had an average test-day yield higher than farms with RM and $2 \times$ (Table 2 ).

To approach the effects of the change in the milking frequency on a farm, i.e., within the same management, data before and after the change were registered and compared within each farm. Data from four types of milking frequency change are presented in Table 3.

Significant increase in milk yield is observed when a change in milking frequency from $2 \times$ to $3 \times$ occurred (from 26.2 to $31.5 \mathrm{~kg} / \mathrm{d} ; P<0.001$ ) and when a change in milking frequency occurred from $2 \times$ to RM (from 25 to $27.2 \mathrm{~kg} / \mathrm{d} ; P<0.001)$. Those increases per farm are

Table 2. The average yield expressed in $\mathrm{kg} / \mathrm{day}$ in the three milking frequency groups: $2 \times$ and $3 \times$ per day and robotic milking (RM).

\begin{tabular}{llc}
\hline $\begin{array}{l}\text { Milking } \\
\text { frequency }\end{array}$ & $2 \times$ & $3 \times$ \\
\hline Number of farms & 376 & 64 \\
Average number of registrations (tests days $\times$ number of cows) & 2039 & 87 \\
Average milk yield (in kg/d) \pm SD & $24.4 \pm 1.76^{\text {a }}$ & 2091 \\
\hline
\end{tabular}

a,b,c Means within rows with different superscripts are significantly different $(P<0.001)$. 
Table 3. The average yield in $\mathrm{kg} / \mathrm{d}$ in the three groups before and after the change to another milking frequency, $2 \times$ or $3 \times$ per day or robotic milking (RM).

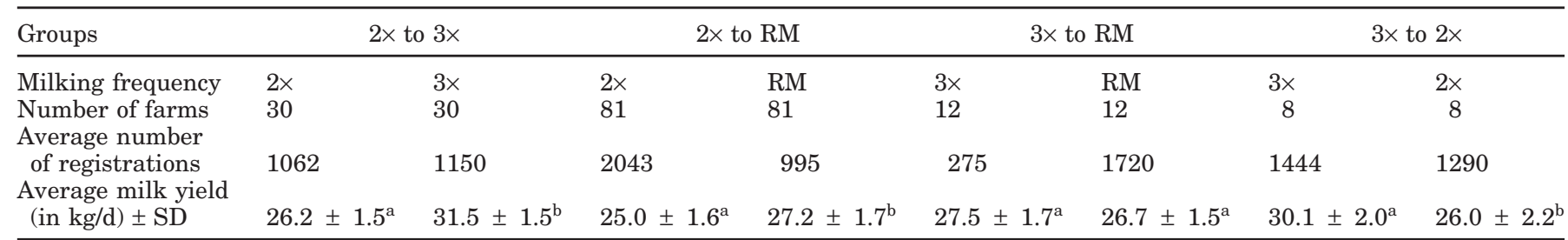

${ }^{\mathrm{a}, \mathrm{b}}$ Means within rows and pairs of columns with different superscripts are different $(P<0.001)$.

illustrated in Figures 1 and 2, respectively. The observation that the change over from $2 \times$ to $R M$ on some farms (see Figure 2) led to a lower milk yield had a strong effect on the overall average milk yield by the robot. There was no significant change in average milk yield after changing from $3 \times$ to RM. That small sample of farms $(n=12)$ had lower average $3 \times$ milk yields at the start than other herds milking $3 \times$. After changing from $3 \times$ to $2 \times$, the average yield decreased substantially (Table 3).

\section{Fertility}

The influence of milking frequency on fertility has been measured by monitoring the NR56 and number of days to first service (Table 4). If the four groups of changed milking frequency are considered, no significant differences in NR56 exist. The relation between NR56 and the average milk yield for the three milking frequencies is presented in Figure 3, illustrating that the NR56 rate decreased slightly as production increased, regardless of milking system. The number of days to first service increased significantly $(P<0.001)$ after the change from either $2 \times$ or $3 \times$ milking to $\mathrm{RM}$ (Table 4).

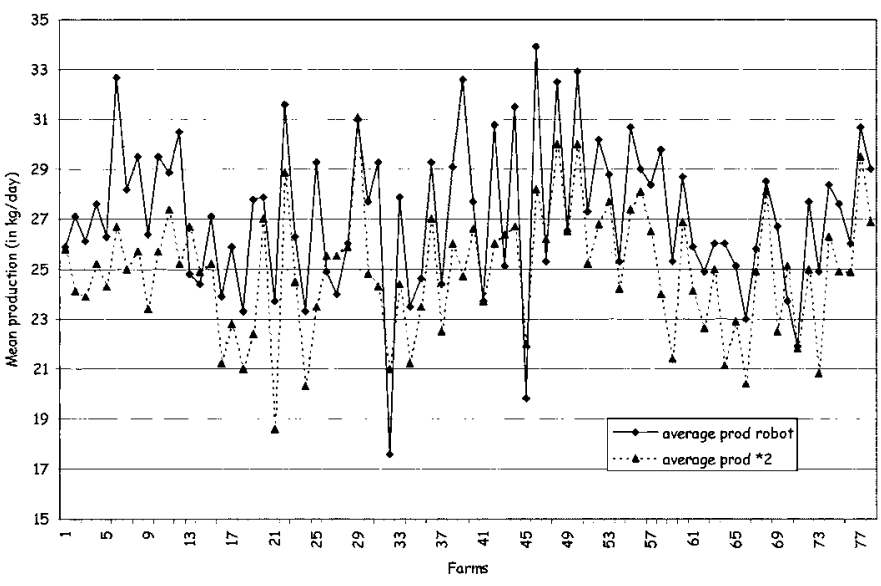

Figure 2. Mean production on 81 farms at the change from $2 \times$ to robotic milking. $\operatorname{scc}$

The average SSC for the three different milking systems are presented in Table 5. The mean SCC was always higher $(P<0.05)$ in the RM group than when those same herds had been previously milked either at frequencies of $2 \times$ or $3 \times$. Changing from $2 \times$ to $3 \times$ or vice versa did not significantly affect SCC.

\section{DISCUSSION}

\section{Milk Production}

The presented data confirm the results obtained by others, demonstrating that more frequent milking leads to more milk yield (Amos et al., 1985; Barnes et al., 1990; Hillerton and Winter, 1992; Erdman and Varner, 1995; Kruip et al, 2000). The average milk yield in kilograms per day for a milking frequency of $3 \times$ was higher compared to the group with the milking frequency of $2 \times$. This finding is in agreement with the conclusion of Erdman and Varner (1995), which was based on 19 reports in the literature. The mean production obtained with the RM lies in between the average productions of groups milked at $2 \times$ and $3 \times$. Although the actual milking frequency of RM was not recorded in the current study, the average yield fits into the estimation of the average milking frequency that we made in an earlier study of RM: in which the frequency was 2.7 times per day (Kruip et al., 2000). The changes in average milk yields in kilogram per day were most obvious when the milking frequency was changed from $2 \times$ to $3 \times$ and from $2 \times$ to RM. The increase of average yield in kilograms per day after changing over from $2 \times$ to $3 \times$ is in theory about $15 \%$, varying from about 10 (Klei et al., 1997) to about 25\% (Amos et al., 1985; Campos et al., 1994) and in agreement with our finding of $20 \%$. The increase in average milk yield in kilograms per day after change from $2 \times$ to RM was unexpectedly low (Table 2). This was probably due to the fact that the change to RM did not always result in an increase in milk yield in all herds. In this respect, it is relevant to mention that the intervals between milkings for $2 \times$ and $3 \times$ were very regular, whereas milking intervals 


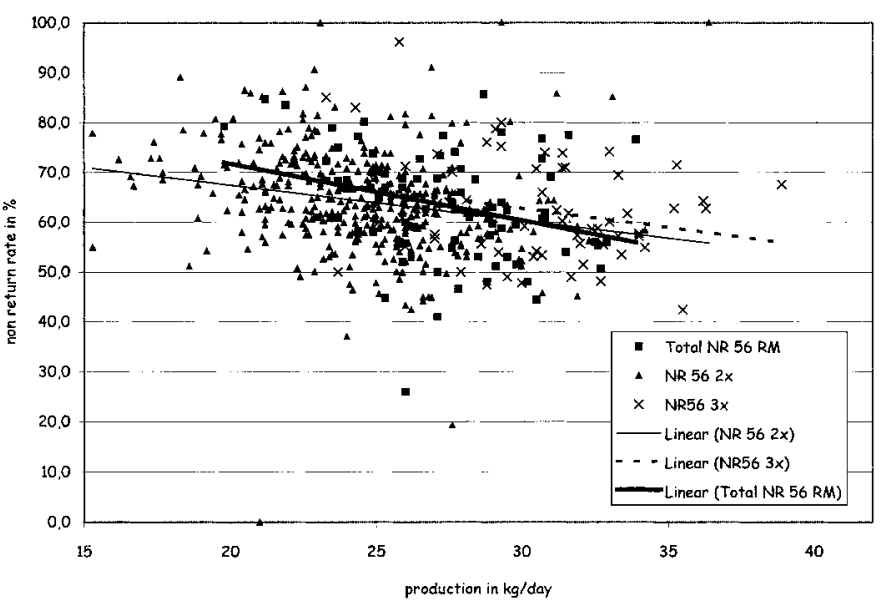

Figure 3. Nonreturn rates for the three milking groups as a function of production.

in the RM system might be much more irregular (Winter and Hillerton, 1995; Ketelaar-de Lauwere et al., 1999). We would like to speculate that the regularity of the intervals between milkings has some benefits and leads to more production (Figure 1). On the contrary, irregular intervals between milkings might lead to milk accumulation in the alveoli and less production by the secretory cells due to the autocrine down regulation of production (Knight and Wilde, 1993; Knight et al., 1994; Knight and Dewhurst, 1994). Fewer and irregular visits to the robot might count for the lower production in the change from normal milking to RM for some farms.

\section{Fertility}

From the literature, interactions between milk yield and reproduction have been observed (Butler and Smith, 1989; DeVries and Veerkamp, 2000). Shortly, yield increase leads to a deeper negative energy balance (NEB) postpartum and by that to lower levels of both glucose and insulin. In some respect, insulin is the driving force of reproduction (Kruip et al., 1999; 2001). Because a higher frequency of milkings leads to a higher yield but not to a proportional increase in feed intake, it consequently leads to a deeper NEB. Indeed, Butler and Smith (1989) explained the fact that the depth of the NEB was directly related to a longer postpartum interval to first ovulation and lower conception rates. Based on that observation we expected a reduction in fertility as milking frequency increased. However, under experimental conditions, most of the studies showed that more frequent milking does not delay the occurrence of estrus (Poole, 1982; Stefanowska et al., 1996;). Amos et al. (1985) also indicated that reproductive performance was not influenced by the milking frequency. 


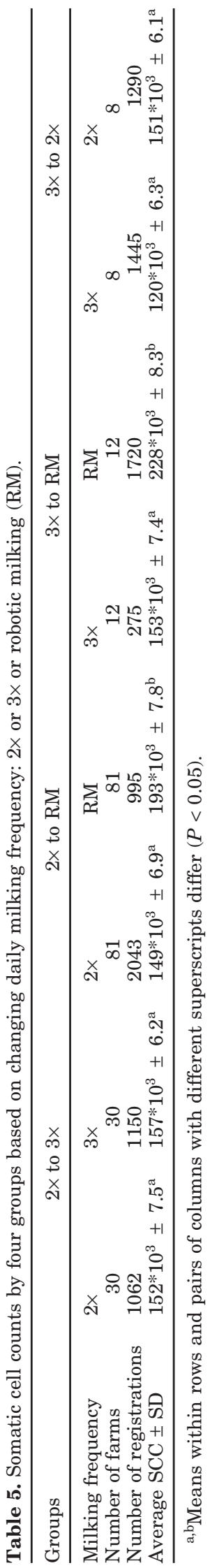

In this connection, the problem of the limited number of cows in the experimental studies (Amos et al., 1985; Stefanowska et al., 1996) had been raised, making the question relevant whether under practical conditions, with a higher number of animals and a less controlled environment, the same conclusions would be reached.

Indeed, according to the results that we obtained on Dutch cattle, we have to conclude that the detected higher milk yield following the change from $2 \times$ to $3 \times$ milking/day does not lead to a significant reduction in fertility, as measured by the NR56 nor for the days to first service. That finding is different from other studies for the relationship between milk yield and fertility. Therefore, a regression analysis on the milk yield versus NR56 was made and presented in Figure 3. This figure clearly showed that for the three groups, the NR56 is negatively correlated with milk yield. Herds with a higher milk yield within a given milking frequency had, on average, a lower NR56. In addition to that and different from what occurred when the milking frequency was $3 \times$, the $R M$ induced an increase in the number of days to first service (Table 4). This observation is hard to explain, as it cannot be caused by higher milk yield. In our opinion, this observation is the result of the fact that the number of days to first service is a subjective measure, as it largely depends on the farmer's management (Rossing et al., 1998). It might be that, although the RM farmer theoretically has more time to observe his animals for estrous detection, the farmer may actually not be among the cows as much and other farm or nonfarm activities may have a higher priority than estrous detection. The NR56 after first insemination is a more objective measure for cow fertility than the number of days to first service. However, the NR56 of the RM group in this study is biased by more days to first service. The more days between parturition and first service the more chance that the involution of the uterus is completed and the fertility improved. A better measure would have been the days from calving to first ovulation, but this measure is not available under practical conditions. As long as feed management is adequate to meet the demands for lactation and maintenance, fertility is not affected by robotic milking. In conclusion, we can state that RM has no apparent negative effects on fertility.

\section{SCC}

It appeared from our study that milking frequency up to $3 \times$ in general does not affect average SCC. In a study comparing the effects of $2 \times$ versus $4 \times$ milking on udder health, Hillerton and Winter (1992) concluded that udder health will be improved by an increased frequency of milking, given application of good hus- 
bandry. Those authors mention the possibility of a reduction in the incidence of some forms of mastitis. However, it is a concern that we observed significantly higher SCC in herds using the RM system. This is in accordance with the findings of Klungel et al., 2000. It is clear that direct comparisons of effects of $\mathrm{RM}$ and conventional milking are difficult because the systems differ in more ways than milking frequency alone. Factors such as the regularity of milking, the way of cleaning teats, wet or dry, and the health of the milk canal may be involved. The fact that the milk canal is more open in RM over the day and the canal epithelium is more at risk by more frequent milking may be an issue. Petermann et al. (2000) concluded from the data of their study that quarters with a high maximum milk flow have a higher risk for IMI. However, there are enough data to expect that with more experience and attention to detail with all aspects of RM and by further improvements in teat cleaning that effects of RM on increasing SCC can be attenuated.

\section{REFERENCES}

Amos, H. E., T. Kiser, and M. Loewenstein. 1985. Influence of milking frequency on productive and reproductive efficiencies of dairy cows. J. Dairy Sci. 68:732-739.

Barnes, M. A., R. E. Pearson, and A. J. Lukes-Wilson. 1990. Effects of milking frequency and selection for milk yield on productive efficiency of Holstein cows. J. Dairy Sci. 73:1603-1611.

Butler, W. R., and R. D. Smith. 1989. Interrelationships between energy balance and postpartum reproductive function in dairy cattle. J. Dairy Sci. 72:767-783.

Campos, M. S., C. J. Wilcox, H. H. Head, D. W. Webb, and J. Hayen. 1994. Effects on production of milking three times daily on first lactation Holsteins and Jerseys in Florida. J. Dairy Sci. 77:770-773.

Devir, S., J. A. Renkema, R. B. M. Huirne, and A. H. Ipema. 1993. A new dairy control and management system in the automatic milking farm: Basic concepts and components. J. Dairy Sci. 76:3607-3616.

DeVries, M. J., and R. F. Veerkamp. 2000. Energy balance of dairy cattle in relation to milk production variables and fertility. J. Dairy Sci. 83:62-69.

Hillerton, J. E., and A. Winter. 1992. The effects of frequent milking on udder physiology and health. Pages 201-211 in Proc. British Mastisis Conference, Stoneleigh, UK.
Erdman, R. A., and M. Varner. 1995 Fixed yield responses to increased milking frequency. J. Dairy Sci. 78:1199-1203.

Ketelaar-de Lauwere, C. C., A. H. Ipema, E. N. J. van Ouwerkerk, M. M. W. B. Hendriks, J. H. M. Metz, J. P. T. M. Noordhuizen, and W. G. P. Schouten. 1999. Voluntary automatic milking in combination with grazing of dairy cows: Milking frequency and effects on behaviour. Appl. Anim. Behav. Sci. 64:91-109.

Klungel, G. H., B. A. Slaghuis, and H. Hogeveen. 1999. The effect of the introduction of automatic milking systems on milk quality. J. Dairy Sci. 83:1998-2003.

Knight, C. H., and C. J. Wilde. 1993. Mammary cell changes during pregnancy and lactation. Livest. Prod. Sci. 35:3-19.

Knight, C. H., D. Hirstand, and R. J. Dewhurst. 1994. Milk accumulation and distribution in the bovine udder during the interval between milkings. J. Dairy Sci. 61:167-177.

Knight, C. H., and R. J. Dewhurst. 1994. Once daily milking of dairy cows: Relationship between yield loss and cisternal milk storage. J. Dairy Sci. 61:441-449.

Kruip, T. A. M., G. A. L. Meijer, T. Rukkwamsuk and T. Wensing. 1999. Investigation into the mechanisms of reduction in fertility of high yielding cows. Pages 183-190 in Production Diseases in Farm Animals. Proc. 10th Int. Conf. 1998. T. Wensing, ed. Wageningen Pers.

Kruip, T. A. M., J. Stefanowska, and W. Ouweltjes. 2000. Robot milking and effect on reproduction in dairy cows: A preliminary study. Anim. Reprod. Sci. 2016:1-5.

Nebel, R. L., and M. L. McGilliard. 1993. Interactions of high milk yield and reproductive performance in dairy cows. J. Dairy Sci. 76:3257-3268.

Petermann, M., W. Wolter, C. Kotting, B. Kloppert, H. Seufert, and M. Zschock. 2000. Single quarter milk flow profiles and rate of subclinical mastitis in automatic milking systems. Pages 120-121 in Robotic Milking. Proc. Int. Symp. Lelystad, The Netherlands.

Poole, D. A. 1982. The effects of milking cows three times daily. Anim. Prod. 34:197-201.

Rossing, W., E. Aurik, and W. Smit. 1998. Robot milking systems and the integration in the dairy farm. Pages 182-194 in National Mastitis Council Annual Meeting Proceedings. National Mastitis Council, Madison, WI.

Stefanowska, J., H. Hogeveen, S. Devir, and E. Benders. 1995. Occurrence of estrus in frequently milked cows in an automatic milking system. J. Dairy Sci. 78(Suppl. 1):278. (Abstr.)

Stefanowska, J., S. Devir, H. Hogeveen, and E. Benders. 1996. The influence of frequent milking on oestrous cycling of dairy cows milked automatically. Dienst Landbouwkundig Onderzoek. Rapport 96-07 imag-dlo, The Netherlands.

Waterman, D. F., R. J Harmon, R. W. Hemken, and B. E. Langlois. 1983. Milking frequency as related to udder health and milk production. J. Dairy Sci. 66: 253-258.

Winter, A., and J. E. Hillerton. 1995. Behaviour associated with feeding and milking of early lactation cows housed in an experimental automatic milking system. Appl. Anim. Behav. Sci. 46: $1-15$. 